\title{
MAINTAINING A POLITICIZED CLIMATE OF OPINION? EXAMINING HOW POLITICAL FRAMING AND JOURNALISTIC LOGIC COMBINE TO SHAPE SPEAKING OPPORTUNITIES IN UK ELITE NEWSPAPER REPORTING OF CLIMATE CHANGE
}

\author{
Julian Matthews \\ Department of Media and Communication, University of Leicester
}

Authors' final version of:

2015. Maintaining a Politicized Climate of Opinion? Examining how Political Framing and Journalistic Logic Combine to Shape Speaking Opportunities in UK Elite Newspaper Reporting of Climate Change. Public Understanding of Science (September 7, 2015. doi: $10.1177 / 0963662515599909$ )

\begin{abstract}
This paper explores the importance of issue politicization and mediation for the reporting of climate change in UK elite newspapers. Specifically, this investigates how journalistic logic mediates political framing to produce commentaries on and discussion about climate change in the news. In analysing elite newspaper coverage over time in this case, the paper shows that (i) various frames introduce the issue as a legitimate problem within coverage and that the (ii) news stories these inform are opened to specific commentaries according to "elite journalistic logic'. This configuration of coverage orders the speaking opportunities of established voices of science, politics and industry as well as those less established voices that enter to explain and qualify these elite accounts. The paper concludes that the ingrained combination of issue politicization and journalistic logic observed here will likely shape future elite reporting and those voices that it will include.
\end{abstract}

Key words: journalism, climate change, framing, news access, news voices, legitimation, journalistic logics, politicization 


\section{Introduction}

Research has recognised that fluctuations in news coverage reflect wider processes of politicization and mediation rather than 'real' levels of the intensity or seriousness of the environmental issues these report (Hansen 1993). These processes are often examined separately and the analysis of politicization for example uncovers the communicative activities of politicians, scientists and industry spokespeople alongside pressure groups as providing important raw material for media coverage. How then journalists select and shape this material into news accounts comes under the academic province of mediation. Mediation is a dynamic process that determines the forms that these perspectives and voices will adopt in coverage, informing for instance their selection according to the prominence of natural or political events (Carvalho 2007) along with concerns over the available space and time in news reports. Other practices that shape story writing in the process govern the presentation of issues and the speaking opportunities in the final reporting (see Anderson 2003). Research pursued in these directions has made significant gains in explaining the visibility of issues. Nevertheless, their advances have said little about the dynamics that shape both the character of news issues and various opportunities for voices they provide.

In response, this article addresses the connection between the processes of politicization and mediation of the climate change issue. It recognises that the politicization process is reproduced in those political frames that appear in reporting and that in their place these frames provide a foundation on which news coverage develops. Still, these frames are not reproduced wholesale within and across the media. Rather they undergo mediation and through the process it is the 'logics' associated with different news forms (e.g. 'elite', 'midmarket' and 'downmarket') that shape their position and reporting in the news. To explore this point and map the consequences of newspapers' reporting of political frames mediated by 'elite journalistic logic', this paper will examine UK elite newspaper coverage over ten years (2000-2010). This will show that significant patterns in the reported voices and discussion in UK elite news coverage of climate change appear because of 'issue legitimacy' offered by political framing combining with the 'dialogic openness' of elite logic.

\section{Politicization, news media and climate change}

It is important to grasp that which motivates issue politicization to be able to understand the forms that political frames adopt and how these appear in news reporting. Habermas (1998/1976) discusses political reaction to 'significant' issues in his book 'Legitimation Crisis'. It states that some issues represent 'crisis tendencies' in advanced capitalism because the state can no longer mediate their 'negative outcomes' in its general role to manage (welfare) capitalism. Climate change is introduced there as a pertinent example alongside other issues that are destined to become politicised in this way. The process of 'politicisation' (Habermas 1971; 1998/ 1976) grows intense in the interactions between the state, political actors and other interest groups. Through dialogue, the state and political actors attempt to sustain their legitimacy (in representing their action in the face of climate change) while other interests challenge these attempts as part of their alternative accounts and voiced criticism. That climate change or other issues share 'crisis tendency' status and contain the seeds to grow a wider crisis in political legitimacy has been critically reviewed (e.g. Held 2006). Nonetheless, practices to promote ills associated with environmental despoliation and to evaluate the actions of government and other actors are introduced repeatedly to be features of the 'late modern', 'risk' or 'network'- society (Beck, 1992; Castells 1997; Eder 1996). This wider literature introduces various forums involved in this politicisation process but it pays less attention to the forum offered by the mass media. It is 
unfortunate also, that media research says little about the organised politicization process that shapes news coverage. What this literature does include, however, are insights into the outcomes of the efforts of actors to sustain and challenge political legitimacy to which we will now turn.

\section{Frames and voices}

Overviews of climate change reporting introduce important observations into: (i) the types of frames in coverage that represent outcomes of the politicization process and (ii) how these mediated understandings alter in coverage over time (see Cottle 2009). Early research has shown how the issue developed prominently in coverage across the 1980s (Wilkins and Patterson 1991) and reproduced there science framing on the 'problem' and 'cause' of the issue and political frames that spoke of this in terms of 'judgements' and 'remedies' (Trumbo 1996). Significant also within this coverage was the greater latitude given to political frames to shape these news discussions. In later accounts of the issue (1985-2003), this dual configuration of frames is observed as undergoing a slow transformation. Political frames continue to dominate the period but within a new form that remarks increasingly on the dangers of climate change (Carvalho and Burgess 2005). Similarly, a new framing of climate science accompanies these changing political frames and this deviates from those unproblematic accounts found in earlier periods (Weingart et al 2000). In moving to discuss changes in the 2000s, research comments on the uptake of climate science scepticism in the news (Carvalho 2007).

At this time, greater amounts of scepticism frames emerge in US coverage (see Antilla 2005) and spread also across other reporting. In privileging particular events or 'episodic frames', the news journalism over this period, Boykoff and Roberts (2007) argue, allows disagreement over the science of climate change and political controversy to penetrate their general accounts. Still, subsequent overviews of coverage and other research (Cottle 2009) witness this framing as later retreating. Significant in the later 2000s, for example, is the reporting of high profile international political gatherings and summits and how coverage frames these events in terms of 'conflict' and 'negotiation' (Lockwood, 2010; Berglez et al 2010). The dominance of international political relations over domestic politics and their combined overshadowing of the framing of climate science (Shehata \& Hopmann 2012; Gordon et al 2010) also mark this observed period. Remarked similarly as central to reporting at this time is the framing of the 'impacts' of climate change and the relationship between the issue and economics or industry. Zehar (2010) suggests that business coverage frames the climate change issue increasingly in terms of economic solutions rather than the technological fix frames recognised as present within previous coverage (see Wilkins and Patterson 1991). Of course, variations in reporting exist within the outlined continuities and these reflect the priories of the news ecologies of different countries (Howard-Williams 2010; Boykoff and Rajan 2007) and the preferred ideological worldviews of individual newspapers (Carvalho and Burgess 2005:1458). Still, how do these observed outcomes of the politicization process shape the presence of voices in coverage?

Unfortunately, studies that explore the presence of news voices in coverage tend not to discuss their findings in context of issue framing. Rather their attention is focused on the discursive nature of stories. However, these do show outcomes from politicization in the way they introduce coverage privileging elite voices and positioning these speakers according to their respective motivations. Politicians, these explain, serve in their highly visible position in coverage to define and shape the political contours of news discussions (Gabor 2000). Elites from the commercial sector take opportunities alongside politicians to define the business 
case (Linne 1993) that includes proposing economic 'fixes' (Zehar 2010) in addition to representing business interests. Moreover, scientists feature frequently in coverage to introduce the science behind climate change. In their appearances, they either actively mediate (or limit) their exposure in accordance with a distrust at the way journalists represent their expertise within the politicised issue (Nelkin 1995) or simply attempt to gain commensurate attention to those often covered 'maverick' type scientists (Tosse 2013). An additional feature that concerns research is the prevalence of pseudo experts that voice organised climate science denial (Monbiot 2007; Holmes 2010). The presentation of these elite voices further moulds coverage and this is unwittingly assisted when news journalism favours stories on controversial science (Friedman et al. 1999). Nonetheless, there is a greater diversity within news discussions than that observed between elite voices. This reporting also features the alternative definitions offered by environmental groups and other interests (Doyle 2007; Anderson 2003; Linne 1993), who in gaining access to the news have their views positioned in relation to elite commentary. A consequence of this predicament is that interest groups become the catalyst of a discussion on an issue rather than as the voice that defines it or makes recommendations about it (Hansen 1993).

\section{Politicization, framing and journalistic logic}

Combined, these studies of frames and voices provide valuable insights into the staged process of the national politicization of the climate change issue. The recoded frames show that political discussions are offering legitimacy to the issue and placing climate change within a sphere of 'legitimate controversy' than the spheres of 'consensus' or 'deviancy' (Hallin 1985). Such judgements and the raw material of political framing on the issue as other research argues are important as they influence how journalists will describe and react to the issue in their reporting (Reese et al 1992).

However, there is more to the mediation process than observing these insights into the reproduced judgements and frames. Studies of journalism stress the importance of the general structures and processes of the news production process that shape the characteristics of reporting (see Anderson 1999). Contrary to adopting a homogenised view of journalists work however, we can introduce in its place a concept that recognises diversity among journalists' practices. This paper adapts the concept of 'journalistic logic' not to demonstrate the influence of commercially infused media story formats as has been done elsewhere (e.g. Altheide 2002) but to represent logics at play in newspapers who occupy different market positions (i.e. 'elite', 'mid market' or 'lower market'). Of these logics, elite journalistic logic will be studied here as it ensures that the elite newspapers cover a wide range of political and economic issues along with those views and opinions that accompany them. Similar to their contemporaries in the news ecology, elite newspaper journalists apply their logic to mediate the raw materials that issue framing provides into recognised elite news stories. What follows will seek to explore the outcomes of when elite journalistic logic meets the political framing of climate change in UK newspaper reporting. However, first a few words on the study on which this discussion will be based.

\section{Method}

The following discussion reports on research into the politicization and mediation of the climate change issue. The study selected four UK elite newspapers (The Times, The Telegraph, The Independent and The Guardian) and collected a ten-year sample of their coverage ( $1^{\text {st }}$ Jan $2000-31^{\text {st }}$ Dec 2010 ) to explore potential changes in the elite reporting of the issue. In searching for individual articles, it employed the basic search terms 'global 
warming' and/ or 'climate change' in the lexis nexis database. After cleaning for duplicate or non-relevant stories, the researcher adopted every $10^{\text {th }}$ article consecutively across their coverage to produce a random sample of 1379 stories. These stories were then taken forward for analysis.

This analysis was conducted in two phases. The first phase examined characteristics of coverage to grasp the legitimacy given to the issue, including: (i) frames, (ii) story themes and (iii) the causes behind their writing. As part of this process, a systematic technique was used to identify the presence of a dominant frame in each story. The procedures of linguistic analysis (see Baker and McEnery 2005) inspired this process and in practice these helped to record the relationships between proximate wording and develop these into frames that represent the coverage ${ }^{i}$. Specifically, this process located the wording 'climate change' or equivalent in the headline and/ or beginning of the news story before tracing the syntactic patterns between it and other proximate words (or a concordance). Through a simple process of pairing together similar observations, these patterns were placed into categories. When the analysis was complete, eight frame categories remained, including: (i) climate change as an issue to combat; (ii) threat /risks of climate change; (iii) effects / predictions of climate change; (iv) climate change as a scientific process; (v) scepticism of climate change; (vi) talk /debate about climate change; (vii) action on climate change and (viii) inaction on climate change. The individual headlines observed in the process were then compared with the rest of their stories to produce categories on the (i) story themes and (ii) the expressed cause behind their writing and both were analysed as part of a general content analysis.

The second phase examined those news voices produced by elite journalistic logic. Within this phase, a content analysis was used to explore the ordering and placement of voices in news stories. Part of the process examined the 'news formats' used to position news voices in the coverage and this used categories adapted from Cottle and Rai (2006) in the process. The applied formats included those of: (i)'authority' which allows the voice to define the issue; (ii)'contest' which positions voices in direct contest which each other, (iii)'contention' which introduces contending voices but not direct contest and (iv) 'community service', which includes the voice of the journalist and explains the relationship between the issue and the audience. In addition, the analysis recorded the professional / institutional backgrounds of individual news actors and recoded the list of individual voices into eight groups, including those of: domestic politician, international politician, industry, scientists, public institutions, interests groups and associations and individuals. Following this process, the study measured the position of each voice and their types of entry into the news story. Their entrance into the news was noted as adopting one of three positions, which included either (i) the 'news reference', (ii) the 'attributed statement' or the (iii) 'quoted speech'. Observed in addition to their news entry was the role that news voices would play in the story, including the offering of either: a 'statement', an 'explanation', an 'evaluation', a 'recommendation' or a 'reaction'. Finally, the analysis compared the findings from the mediation of content and the voices to assess links between them. This produced the interesting insights that will be introduced next.

\section{Findings}

This section will explore the relationship between the observed frames and voices in the UK newspaper coverage. In examining the amount of coverage first, we can observe there are similarities and differences in the coverage of the elite newspapers ${ }^{\mathrm{ii}}$ (see figure.1). Of significance in this respect is the Guardian's reporting as this produces a higher proportion of coverage overall than the other newspapers, significantly more coverage than the Telegraph 
over the ten-year period. The differences between these newspapers probably reflect the influence of their ideological stances on the selection of the news topic (Carvalho and Burgess 2005). Their similarities including those growth patterns observed over time, however, come from the environment external to these newspapers. Some studies have suggested that significant newsworthy events (e.g. climate change conferences or moments of controversy, for example) generate levels of media attention. This is true but significant events are only part of a wider process of politicisation. The politicisation of climate change or in other words the elite efforts to frame and speak about the issue shape the similarities we observe in these newspapers' coverage (see Figure 1).
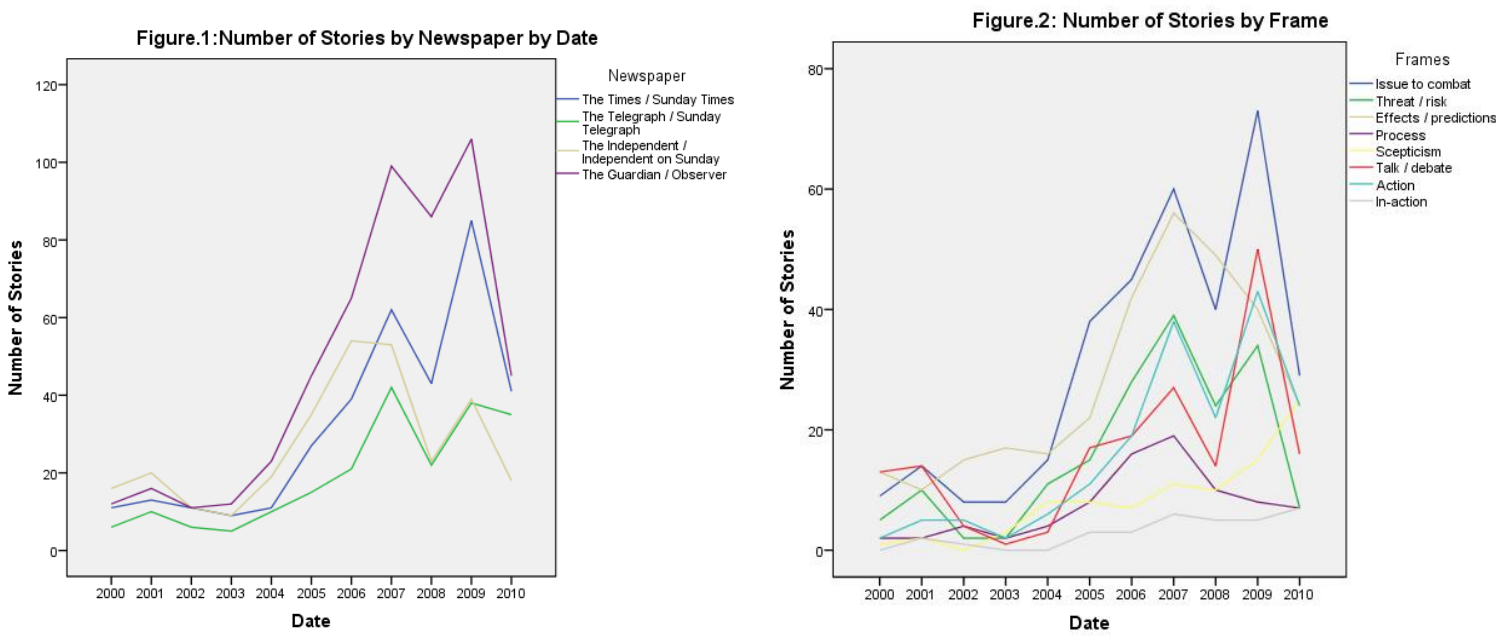

Realising that politicization influences UK coverage encourages us to analyse how these newspapers report the issue. This study addresses this aspect in findings on the eight recognisable frames that construct climate change (see Figure.2) and how their number peak and trough across the 2007 and 2009 period. The amounts in which these frames appear in coverage show that these multiple understandings are shaping the reporting over this period. Further as newspapers reproduce this politicisation of the issue, they are bringing continuity to coverage and to its discussion of the legitimacy of climate change. Expressed in board terms, the climate change issue is introduced in coverage as (i) a 'real process', which is explained to have tangible (ii) 'effects' and (iii) potential future 'risks / threats'. As defined by these outcomes the issue is introduced as also requiring (iv) 'combating' and as a subject of 'action' and 'inaction', among other understandings. This reading of frame content provides a general insight into the issue politicization that has informed the coverage across the period. However, this is only part of the picture. As we have heard, news journalists play a role in mediating the wider politicization of climate change into news coverage and some employ elite journalistic logic for this purpose. What follows will explore news coverage produced according to the wider politicization of climate change (frames) and the elite journalistic logic that shapes elite news coverage. We will hear of the relationship between voices and 'frames' (see Table.2 in appendix), 'communicative format' (see Table.1 in appendix), 'news entry' and 'news roles' (see Table.3 in appendix) - all of which explain the selection and positioning of voices in the news. This discussion begins by examining voices in the most prominent frame, the issue to combat frame. 


\section{Issue to combat}

Previous research shows that climate change coverage differs according to the reporting of stories that introduce its 'legitimacy' and those that do not. The UK coverage studied here provides a clear and straightforward representation of the issue. Climate change is presented as a legitimate issue that requires elite attention (or combating) in significant numbers of stories (965 stories - see Table.2) and these dominate those in other frames and are shown to build across time. Further, this representation captures political discussion existing beyond the nation. Although stories represent the desire to combat ('fight', 'tackle' and 'deal with'...) the issue in discussions of national politics and the economy, these also use the frame to introduce and explain a UK perspective on international relations. Those that initiate these stories explain the focus of the coverage and it is reports or voiced statements offered by politicians and business representatives that underpin most of the accounts on combating climate change.

Such insights support Habermas' claim that political elites proactively comment on issues to sustain their general authority (to tackle the issue). We can extend our thoughts on this observation to include the similar performance of business elites and acknowledge that this group follows the approach outlined by UK politicians. Business voices feature in prime opportunities to discuss combating the issue for example ('authority format' - see Table.1) alongside politicians, scientists, public institutions, and interest groups. Noteworthy, however, are the variety of these performances. Whereas elites (politicians, scientists and industry spokespeople), make demands for climate change to be addressed and evaluate others' actions, other non-elite voices feature to offer evaluations (including interest groups and associations and individuals - see Table.3). Significant is how framed coverage offers opportunities to these (interest groups, predominately) to evaluate elite perspectives on combating climate change. These commentaries often overshadow the evaluations that elites provide and form a pattern can be similarly observed in other framing, including that based on effects and predictions.

\section{Effects/ predictions}

Sustained UK news coverage on the effects and predictions of climate change further underpins the representation of the legitimacy of climate change that is observed above. Previous research notices that actual or predicted impacts of climate change are reproduced often in science-based news discussions. Although this type appears frequently in this coverage, UK reporting of effects and predictions is expanded to include the perspective of politics and industry alongside science (734 stories - see Table.2). Stories follow a scientific focus to explain selected impacts and consequences of climate change and draw on other foci to explain effects and predictions in context of the domestic economy and politics. Noticeable distinctions in the appearance of stories come also from the claims making activities of actors that initiate them, including the discursive work of scientists and politicians alongside small numbers of others.

Another feature of this frame is the uncontested nature of the effects and predictions that these stories describe (see Table.1). As present, it reflects the relationship between story content and the accompanying news commentaries. Nearly two thirds of these stories allow voices to speak with authority and to define the contours of story content (199 stories of out 304 - see Table.1). Stories offer those opportunities to scientists mostly and these voices in their place reinforce the authority of scientific explanations of the climate change issue. Appearing across the frame, scientists define, explain and evaluate effects and predictions of 
the issue and moreover their views are included to complement one another. Elsewhere, the voices of the representatives from politics and industry make comments on the implications of climate change for domestic political or economic concerns, but in their position, they receive less space than non-elite voices. Habermas' observations on those whom contest the climate change issue is supported by the presence of interest groups and associations recorded here and how their statements, explanations and evaluations on effects appear in greater number and overshadow the reflections offered by elite voices in coverage. Non-elite voices are also present in frames that embrace deliberation on the importance of climate change issue such as the 'talk / debate' frame.

\section{Talk / debate}

Hitherto, the UK coverage has been discussed as framing climate change as a significant issue with important effects. In addition to this, the UK coverage introduces discussions of the formalised political processes where the effects and their implications and other matters are discussed. Coverage in the 'talk/ debate' frame (521 stories - see Table.2) that peaks in frequency at 2007 and 2009, introduces the process as occurring in three spheres of formalised elite discussion, including those of (i) climate change conferences and summits, (ii) domestic political discussions and (iii) those among business and industry representatives. International political conferences are the first of these (such as those reported in 2007 \& 2009) that shape the presentation and parameters of a significant number of stories. It is nevertheless, the claims making of significant international politicians, domestic politicians and industry representatives who initiate coverage and these stories appear alongside a smaller number of others that are made newsworthy by observed disagreements between the UK government and other political leaders when finalising policy agreements.

Combined, this coverage introduces the machinations behind, and outcomes from, elite formalised discussions and this includes formats that reflect the conflict between their positions. The difference between the positions of UK and European representatives on climate change policy is represented within an authority format that allows space for UK political actors to explain their perspectives on some occasions (see Table.1). Nevertheless, these issues are represented most commonly in contention formats that order the included positions that are at odds. In other places, coverage introduces UK, European actors and other world political actors (including the US; China and other BRIC countries) as engaged in direct contests over ideas (contest format). Thus, these speaking opportunities are divided between international and domestic politicians mostly with the addition of journalists' voices who appear in stories to explain to reader the significance of what is being said (i.e. community service format - see Table.1). This coverage also includes wider reaction from outside the formalised world of politics (e.g. from science and business) to explain the implications of the talks. Significant in terms of our previous discussion of climate change is the presence of interest groups and associations as included experts. They feature commonly to evaluate the progress of formalised talks and comment in stories on observed gaps between what political actors' say they will do and what they actually do.

\section{Threat / risk}

Framed discussions about the future 'risks' and 'threats' of climate change in the UK coverage reflect the important status attributed to the issue that Habermas and others recognise. These stories appear across the coverage (432 stories - see Table.2) and adopt forms some of which introduce risk as straightforward and uncontested scientific calculations. Other stories in the frame are more discursive in character and these explain the 
general consequences of climate change or explore ideas of 'risk and threat' in the context of particular domestic political and business related discussions. Elites play a role in initiating this coverage and appear in the announcements of scientific research expertise that underpin the reporting of research findings, in addition to discussions of threats and risks that appear elsewhere in the frame and are supported by the proactive communicative efforts of politicians and industry representatives.

Further, there are many voices involved in the framed coverage. An observed diversity in the number of speakers does not produce accounts of risk or threats as politically contested however and further this coverage shows voices (particularly those of scientists and domestic politicians) as working to contextualise these threats in coverage (see Table.1). Any stories about 'threat / risks' themselves normally include a science voice (which explains the overall prominence of scientists in coverage) that will be followed by either a domestic or international politician or a voice from industry (see Table.3). Stories describing 'threats / risk' also provoke wider commentary and offer space for non-elite interpretations as such times. This coverage includes both the voices of individuals and interests groups and associations and it offers support for the view that the latter voices play the position of the critic of other political and industry elites. .

\section{Action}

From the perspective of the previous reviewed literature, the action frame - observed here appears to provide elites with opportunities to demonstrate a legitimate response to the climate change issue. Contrary to this prediction however, the frame coverage (520 stories see Table.2) produces a widened view of 'action' that includes the actions of non-elites. When introducing action, framed stories discuss the planning and introduction of political policies, solutions posed by business representatives and protest action offered by non-elite actors for the most part. As we would expect from observing these story types, these discussions are formed from the claims making efforts of domestic politicians and business leaders and serve to bring attention to their symbolic efforts to tackle the problem. Still, the newsworthiness of protest action and the reports and commentaries that other groups provide also feature as important catalysts for this coverage. This is reflected in the voices that appear in this frame.

Introduced in the discussions of action are the voices of politicians (domestic and international) and interest groups and these appear in positions of authority to speak about climate change policy from different perspectives (see Table.1). In other stories, the coverage widens to include contending rather than direct contested representations of 'action'. This is opened to significant numbers of voices (e.g. politicians, industry, interest groups and associations, individuals) apart from those of scientists, and coverage includes those relationships between voices that are recognised as prominent in other frame content (see Table.3). Domestic politicians gain significant opportunities to offer the largest number of statements and explanations about action ahead of those of industry representatives, for example. Equally present are interest groups and associations who are included to voice evaluations on the 'actions' of others (elites). The 'action' frame appears from this analysis to be a more complex formation than one that reproduces elite claims about their efforts to tackle climate change.

\section{Scepticism}

Previously, it has been suggested that the presence of scepticism and sceptical voices in coverage plays a significant part in challenging the general legitimacy of the issue (e.g. 
Antilla 2005). By contrast, this account of the UK elite newspaper coverage shows that scepticism features infrequently (285 stories - see Table.2). Moreover, when this theme is reported in coverage, these stories introduce reactions to scepticism / controversy rather than provide a discursive platform for those criticisms of climate science that has been recorded previously. The framed coverage is present in a small number of stories and these divide between discussions of 'controversy' (including 'manipulation of data', 'mistakes' and 'blunders' in climate science) and discussions on the reactions to the issues from domestic business and political perspectives. Some coverage is secured due to the newsworthy character of controversy and those efforts of some media organisations to use this to raise questions about accepted ideas and practices of mainstream science. Nonetheless, making up the dominant amount of coverage are stories that challenge scepticism and these originate from the (counter) claims making of scientists and others.

Present within the frame content is a configuration of voices that reflect the various spoken reactions to controversy (i.e. contention format - see Table.1). Scientists dominate in stories and in their position comment most often on those voicing a questioning, if not sceptical, position (e.g. international (particularly US) politicians). Elsewhere, stories provide scientists, politicians, industry and interest groups and associations with authority to shape coverage around their challenges to controversy or general scepticism (see Table.3). The contributions of interest groups and associations mount a strong challenge to sceptic voices and offer the most evaluative statements in these stories, occupying this position in front of domestic and international politicians and a small number of others. The observation that this coverage includes a range of challenges to sceptical positions hosted by elite and non-elite speakers is significant for our general understanding of the character of the UK politicization of the issue.

\section{Process}

So far, we have described how frames and accompanying voices in the UK coverage reinforce the legitimacy of the climate change issue. This frame (climate change issue as a scientific process) offers further support for the legitimacy of the issue. Its small number of stories (225 stories - see Table.2), provides a backdrop against which elite actors base their responses to the climate change issue. Developing from these initial discussions of climate science in this coverage are non-contentious business discussions of climate change, domestic political discussions about government policy and responses from science and others to future change. Frame content on climate research and policy reactions are developed from the announcements of scientific studies and the claims making from those representatives of politics and business most often.

This frame includes a few stories that offer scientists the opportunity to adopt the most authoritative position (authority frame - see Table.1) and others that allow them to offer a greater number of commentaries (including statements, explanations and evaluations see Table.3). Within this coverage, the discussed connections between climate science and society are presented in contending positions. The discussions of policy in particular offer space to interest groups and associations to provide their perspective, before those of public institutions, politicians (particularly domestic politicians) and industry (see Table.3). Moreover, the mixture of configured voices in these discussions of political and business polices afford them opportunities for critical reflection. Consequently, policy in this instance seems to have inherited the accepted controversy that was previously associated with climate science, and this allows interest groups, industry representatives and scientists to offer 
evaluations on the ideas and policies offered by political actors. Indeed, this type of criticism features also in the final frame in the UK coverage.

\section{Inaction}

The final ('inaction') frame in the UK coverage offers potential space to examine those interventions made to deal with the climate change issue, including space for non-elites to voice criticism of the 'failures' of political figures to address the issue. In reality, these stories feature in a reduced number in the UK coverage (90 stories - see Table.2) and direct their attention toward those actors functioning as part of domestic politics, business and industry and international politics mostly. The origins of these stories are more complex than the voiced criticisms from one group directed at another however, and these include criticisms on inaction by elites and non-elites alike. The claims making of domestic politicians, scientists and interest groups act as story catalysts in this frame and their presence informs the formats in which subsequent stories adopt.

As has been suggested, the presence of voices in the inaction frame follows a marked pattern. Important to these accounts is their sustained focus on criticism as this allows some voices to speak in the authority position. Across the coverage, the voices of scientists, interest groups and associations and domestic politicians comment from this vantage point (see Table.1). Still, a more interesting pattern appears when the lens is widened to include the activities of all voices in the frame. As we have recognised previously, interest groups and associations emerge to offer most criticism on the actions of domestic politicians and in these instances lead discussions on the inability of elites to deal adequately with climate change (see Table.3). Furthermore, interest groups are given the most elaborate range of commentary (including statements, explanations and evaluations) on inaction ahead of the voices of politicians, scientists and industry representatives. In sum, this configuration confirms the focus of their communicative power and presence in this coverage.

\section{Conclusion}

This paper has introduced the processes of politicization and mediation as informing the elite UK newspaper reporting of climate change. It has shown that the politicization process shapes how elite newspapers construct their reporting and thus its findings offer a clear challenge to simple assumptions that national elite newspaper reporting will differ significantly according to their ideology or other influences. In this case, the studied newspapers collectively reproduced a number of frames that originated from the UK politicization of the climate change issue. Such findings have allowed us to understand collective transformation in their reporting. In short, UK elite reporting is configured by changes to the levels of these reproduced frame categories rather than a wholesale change where one type of reporting have superseded another one as has been suggested elsewhere (e.g. Cottle 2009). Further, insights into these frame categories have helped to build a sense of the communicative efforts of political, industry and scientific elites and to non-elite actors operating within the UK politicization process. The outcomes of their communicative efforts have produced coverage focused on climate science (in absence of scepticism), international more than domestic political discussion as well as business and civil society commentary on the outcomes from climate change. Offered then is a view of UK reporting that moves forward previous research findings and encourages contrasts to be made between this reporting and reporting produced elsewhere.

Moreover, this paper has extended the narrow focus adopted in research to show that the UK politicization process shapes the boundaries of the discussion of climate change within a 
sphere of 'consensus' (Hallin 1985). The insights adopted from Habermas earlier in the paper help to speculate on the reasons behind this observed legitimacy at this point. Responding to Habermas' predictions, we can say that the state and political actors' are making efforts to have the media record their thoughts and actions on 'tackling the issue', which extends to their chastising of other governments for their inaction. Perhaps these continuing efforts will help to avoid any forthcoming crisis in elite political authority over the climate change issue. Nonetheless, the coverage that subsequently forms on account of their communicative efforts (e.g. to present the issue as legitimate, criticise others, and encourage criticisms from non-elite actors) presents the potential of this reporting to initiate a "slowburn' communicative crisis (Nohrstedt 2010) in the years to come. In other words, if UK politicians efforts are symbolic or tokenistic only as Habermas (1971) seems to suggest then the operation of journalistic logics that we have outlined here will increase the scrutiny and pressure on them- but how so?

In addition to the points raised above, this paper has demonstrated that journalistic logics shape the representation of the communicative activities of these nationally bound elites. In this instance, elite journalistic logic has intensified the range of discussion and criticism and widened the involvement of others in the reporting of climate change. The criticisms and those challenges made to the self-presentation and general inaction of political elites is an important feature of this elite coverage and one that is set to increase and intensify in future reporting. However, this will not necessarily feature in the reporting of other media. To fully grasp the mediation of climate change across the ecology then research will need to examine the mediation of the UK politicization of climate change by media in other market positions (e.g. using mid market and lower market logics) and likewise to include television news coverage that operates according to additional visual constraints. It is likely that the operation of different journalistic logics will produce a differentiated reporting of this issue and offer the opportunity to reflect on the wider influence of the politicization process. Further, the operation of these logics and the wider process that shapes reporting needs to empirically mapped. New research should explore with journalists and prominent news sources their professional understandings of issue politicisation and the logics that shape their activities in writing or gaining access to the news and what connects them. Covering new ground in these areas would significantly enhance our understanding of factors shaping the (future) mediation of this important issue and processes pertinent to political communication generally. 


\section{Bibliography}

Altheide, D.L. (2002). Creating Fear: News and the Construction of Crisis. New York: Aldine de Gruyter

Anderson, A. (1999). Media Culture and the Environment. London: Routledge

Anderson, A. (2003). 'Environmental activism and news media', in S.Cottle (ed.) News Public Relations and Power. London: Sage

Antilla, L. (2005) 'Climate of scepticism: US newspaper coverage of the science of climate change', Global Environmental Change, 15: 338-352

Baker, P. and McEnery, A. (2005). 'A corpos-based approach to discourses of refugees and asylum seekers in UN and newspaper texts' Language and Politics: 4(2) 197-226

Beck, U. (1992). Risk Society. London: Sage

Berglez, P., Hoijer, B and Olausson, U.(2010).' Individualisation and nationalisation of the climate issues: Two ideological horizons in Swedish news media' in T.Boyce and J.Lewis. Climate Change and the Media. Oxford: Peter Lang

Bokoff , M and Rajan, R. (2007) 'Signals and noise: Mass-media coverage of climate change in the USA and UK', EMBO Reports, 8(3) 207-211

Boykoff, M and Roberts, T (2007). 'Media coverage of climate change: Current trends, strengths and weaknesses', Human Development Report Occasional Paper 2007/08. UN Development Programme. http://hdr.undp.org/en/reports/global/hdr2007-

2008/papers/boykoff,\%20maxwell\%20and\%20roberts,\%20j.\%20timmons.pdf (accessed January, 2012).

Castells, M. (1997). The Power of Identity. Oxford: Blackwell

Carvalho, A. 2007 'Ideological cultures and media discourses on scientific knowledge: Rereading news on climate change, Public Understanding of Science, 16: 223-243

Carvalho, A. and Burgess, J. (2005). 'Cultural circuits of climate change in the UK broadsheet newspapers', Risk Analysis, 25(6): 1457-1469

Cottle, S and Rai, M. (2006) 'Between display and deliberation: Analyzing TV news as communicative architecture’, Media, Culture \& Society, 28(2): 163-189.

Cottle, S. (2009). 'Ecology and climate change: From science and sceptics to spectacle and ...' , in S.Cottle (ed). Global Crisis Reporting: Journalism in the Global Age. Maidenhead: OU Press

Doyle, J. (2007). 'Picturing the climat(c)ic: Greenpeace and the representational politics of climate change', Science as Culture, 16(2):129-150

Eder, K. (1996). The Social Construction of Nature: A Sociology of Ecological Enlightenment. London: Sage 
Friedman, S.M., Dunwoody, S. and Rogers, C.L.(1999). Communicating Uncertainty: Media Coverage of News and Controversial Science. London: LEA

Gaber, I. (2000) 'The Greening of the Public, Politics and the Press, 1985-1999' in J. Smith (ed). The Daily Globe: Environmental Change, the Public and the Media. London: Earthscan

Gordon, J., Deinces, T. and Havice, J. (2010) 'Global warming coverage in the media: Trends in a Mexcio city newspaper’, Science Communication, 32(2): 143-170

Habermas, J. (1971). Toward A Rational Society. London: Heinemann

Habermas, J (1998/ 1976). Legitimation Crisis. Cambridge: Polity Press

Hallin, D. (1985). The 'Uncensored War': The Media and Vietnam. Oxford: Oxford University Press

Hansen, A. (1993) (ed.). The Mass Media and Environmental Issues. Leicester: Leicester University Press

Held, D. (2006). Models of Democracy - 3rd Edition. Cambridge: Polity.

Holmes, T. (2010). 'PR, "impartiality” and power in mass media coverage of climate change', in T.Boyce and J.Lewis (eds). Climate Change and the Media. Oxford: Peter Lang

Howard-Williams, R. (2010). 'Ideological construction of climate change', in T.Boyce and J.Lewis (eds). Climate Change and the Media. Oxford: Peter Lang

Linne, O. (1993) 'Professional Practice and Organisation; Environmental Broadcasters and their Sources', in A. Hansen (ed). The Mass Media and Environmental Issues Leicester: Leicester University Press

Lockwood, A.( 2010). 'Preparations for a post-Kyoto media coverage of UK climate policy' in T.Boyce and J. Lewis (eds). Climate Change and the Media. Oxford: Peter Lang

Monbiot, G. (2007). Heat: How to Stop the Planet from Burning. Cambridge, MA: South End Press

Nelkin, D. (1995). Selling Science: How the Press covers Science and Technology, $2^{\text {nd }}$

Edition. New York: W.H. Freeman

Nohrstedt, S.A. (2010). 'Threat society and the media', in S.A. Nohrstedt (ed.)

Communicating Risks: Towards the Threat Society? Gothenbeg: Nordicom

Reese, S.D., Gandy, O.H and Grant, A.E. (eds) (1992). Framing Public Life: Perspectives on Media and Our Understanding of the Social World. London: Routledge

Shehata, A \& Hopmann, D. (2012) Framing Climate Change, Journalism Studies, 13:2, 175192

Tosse, S. (2013). 'Aiming for social or political robustness? Media strategies among climate scientists', Science Communication, 35(1): 32-55

Trumbo, C. (1996). 'Constructing climate change: Claims and frames in US news coverage of an environmental issue', Public Understanding of Science, 5:269-283 
Weingart, P. Engels, A and Pansegrau, P. (2000). 'Risks of communication: Discourses on climate change in science, politics and the mass media', Public Understanding of Science, 9: 261-283

Wilkins, L and Patterson, P. (1991). 'Science as symbol: The media chills the Greenhouse Effect', in L.Wilkins and P. Patterson (eds) Risky Business: Communicating Issues of Science, Risk and Public Policy. London: Greenwood Press

Zehar, S. (2010). 'An environmentalist / economic hybrid frame in US press coverage of climate change, 2000-2008', in T.Boyce and J.Lewis (eds). Climate Change and the Media. Oxford: Peter Lang 


\section{Appendix:}

\begin{tabular}{|c|c|c|c|c|c|c|c|}
\hline \multicolumn{8}{|c|}{ Table 1. Frames by news format } \\
\hline & & & \multicolumn{4}{|c|}{ news format } & \multirow[b]{2}{*}{ Total } \\
\hline & & & Authority & Contest & Contention & $\begin{array}{c}\text { Community } \\
\text { service }\end{array}$ & \\
\hline \multirow[t]{8}{*}{ Frames } & Issue to combat & Count & 125 & 13 & 179 & 22 & 339 \\
\hline & Threat / risk & Count & 88 & 6 & 64 & 19 & 177 \\
\hline & Effects / predictions & Count & 199 & 7 & 89 & 9 & 304 \\
\hline & Process & Count & 30 & 11 & 32 & 9 & 82 \\
\hline & Scepticism & Count & 19 & 8 & 55 & 8 & $\overline{90}$ \\
\hline & Talk / debate & Count & 40 & 9 & 102 & 27 & 178 \\
\hline & Action & Count & 53 & 9 & 99 & 16 & 177 \\
\hline & Inaction & Count & 14 & 4 & 11 & 3 & 32 \\
\hline \multicolumn{2}{|l|}{ Total } & Count & 568 & 67 & 631 & 113 & 1379 \\
\hline
\end{tabular}


Table.2 Comparison of actors by frame

\begin{tabular}{|c|c|c|c|c|c|c|c|c|c|c|}
\hline & & \multicolumn{8}{|c|}{ Frame } & \multirow[t]{2}{*}{ Total } \\
\hline & & $\begin{array}{l}\text { Issue to } \\
\text { combat }\end{array}$ & $\begin{array}{c}\text { Threat / } \\
\text { risk }\end{array}$ & $\begin{array}{c}\text { Effects / } \\
\text { predictions }\end{array}$ & Process & Scepticism & $\begin{array}{l}\text { Talk / } \\
\text { debate }\end{array}$ & Action & Inaction & \\
\hline & $\begin{array}{l}\text { Politician } \\
\text { (domestic) }\end{array}$ & 283 & 82 & 60 & 37 & 35 & 133 & 141 & 23 & 794 \\
\hline & $\begin{array}{l}\text { Politician ( } \\
\text { international) }\end{array}$ & 188 & 54 & 57 & 21 & 39 & 161 & 43 & 11 & 211 \\
\hline News & $\begin{array}{l}\text { Business / } \\
\text { industry }\end{array}$ & 124 & 44 & 47 & 26 & 28 & 37 & 94 & 12 & 125 \\
\hline Actor & Scientists & 147 & 151 & 420 & 87 & 93 & 74 & 72 & 12 & 1056 \\
\hline & Public institutions & 42 & 34 & 21 & 13 & 31 & 28 & 35 & 3 & 207 \\
\hline & $\begin{array}{l}\text { Interests groups } \\
\text { and associations }\end{array}$ & 142 & 54 & 94 & 38 & 47 & 68 & 90 & 24 & 557 \\
\hline & Individuals & 39 & 15 & 35 & 3 & 12 & 20 & 44 & 4 & 172 \\
\hline Total & & 965 & 432 & 734 & 225 & 285 & 521 & 520 & 90 & 1379 \\
\hline
\end{tabular}




\begin{tabular}{|c|c|c|c|c|c|c|c|c|c|c|c|}
\hline \multicolumn{12}{|c|}{ Table3: Comparison of actors and their roles by frame } \\
\hline \multirow{2}{*}{\multicolumn{3}{|c|}{ News Actor }} & \multicolumn{8}{|c|}{ Frames } & \multirow[b]{2}{*}{ Total } \\
\hline & & & $\begin{array}{c}\text { Issue } \\
\text { to } \\
\text { combat }\end{array}$ & $\begin{array}{l}\text { Threat } \\
\text { / risk }\end{array}$ & $\begin{array}{c}\text { Effects / } \\
\text { predictions }\end{array}$ & Process & Scepticism & $\begin{array}{l}\text { Talk / } \\
\text { debate }\end{array}$ & Action & Inaction & \\
\hline \multirow[t]{6}{*}{$\begin{array}{l}\text { Politician } \\
\text { (domestic) }\end{array}$} & \multirow[t]{5}{*}{ Roles } & $\begin{array}{l}\text { Knowledge } \\
\text { statement }\end{array}$ & 205 & 58 & 38 & 23 & 26 & 90 & 95 & 13 & 544 \\
\hline & & Explanation & 51 & 17 & 16 & 8 & 7 & 30 & 35 & 1 & 165 \\
\hline & & Evaluation & 26 & 5 & 6 & 5 & 2 & 13 & 11 & 9 & 81 \\
\hline & & Recommendations & 1 & 2 & 0 & 0 & 0 & 0 & 0 & 0 & 3 \\
\hline & & Reaction & 0 & 0 & 0 & 1 & 0 & 0 & 0 & 0 & 1 \\
\hline & \multicolumn{2}{|l|}{ Total } & 283 & 82 & 60 & 37 & 35 & 133 & 141 & 23 & 794 \\
\hline \multirow[t]{6}{*}{$\begin{array}{l}\text { Politician } \\
\text { (international) }\end{array}$} & \multirow[t]{5}{*}{ Roles } & $\begin{array}{l}\text { Knowledge } \\
\text { statement }\end{array}$ & 133 & 37 & 40 & 15 & 24 & 121 & 33 & 8 & 411 \\
\hline & & Explanation & 41 & 14 & 11 & 4 & 6 & 25 & 7 & 2 & 110 \\
\hline & & Evaluation & 14 & 1 & 5 & 2 & 8 & 14 & 3 & 1 & 48 \\
\hline & & Recommendations & 0 & 1 & 1 & 0 & 0 & 0 & 0 & 0 & 1 \\
\hline & & Reactions & 0 & 1 & 0 & 0 & 1 & 1 & 0 & 0 & 4 \\
\hline & \multicolumn{2}{|l|}{ Total } & 188 & 54 & 57 & 21 & 39 & 161 & 43 & 11 & 574 \\
\hline \multirow[t]{6}{*}{$\begin{array}{l}\text { Business / } \\
\text { industry }\end{array}$} & \multirow[t]{5}{*}{ Roles } & $\begin{array}{l}\text { Knowledge } \\
\text { statement }\end{array}$ & 78 & 26 & 29 & 16 & 18 & 25 & 62 & 5 & 257 \\
\hline & & Explanation & 28 & 12 & 14 & 10 & 7 & 7 & 19 & 5 & 102 \\
\hline & & Evaluation & 18 & 5 & 2 & 0 & 3 & 5 & 10 & 1 & 44 \\
\hline & & Recommendations & 0 & 0 & 1 & 0 & 0 & 0 & 0 & 1 & 2 \\
\hline & & Reactions & 0 & 1 & 1 & 0 & 0 & 0 & 3 & 0 & 5 \\
\hline & \multicolumn{2}{|l|}{ Total } & 124 & 44 & 47 & 26 & 28 & 37 & 94 & 12 & 412 \\
\hline \multirow[t]{6}{*}{ Scientists } & \multirow[t]{5}{*}{ Roles } & $\begin{array}{l}\text { Knowledge } \\
\text { statement }\end{array}$ & 90 & 88 & 246 & 51 & 58 & 55 & 41 & 7 & 636 \\
\hline & & Explanation & 41 & 54 & 149 & 23 & 22 & 15 & 18 & 3 & 325 \\
\hline & & Evaluation & 13 & 5 & 21 & 11 & 11 & 4 & 10 & 2 & 77 \\
\hline & & Recommendations & 3 & 4 & 4 & 1 & 1 & 0 & 0 & 0 & 14 \\
\hline & & Reactions & & & & 1 & 1 & & 3 & & 4 \\
\hline & \multicolumn{2}{|l|}{ Total } & 147 & 151 & 420 & 87 & 93 & 74 & 72 & 12 & 1056 \\
\hline \multirow[t]{6}{*}{$\begin{array}{l}\text { Public } \\
\text { institutions }\end{array}$} & \multirow[t]{5}{*}{ Roles } & $\begin{array}{l}\text { Knowledge } \\
\text { statement }\end{array}$ & 31 & 24 & 16 & 11 & 22 & 16 & 26 & 3 & 169 \\
\hline & & Explanation & 9 & 6 & 3 & 2 & 6 & 3 & 6 & 0 & 35 \\
\hline & & Evaluation & 2 & 4 & 2 & 0 & 3 & 8 & 3 & 0 & 22 \\
\hline & & Recommendations & 0 & 0 & 0 & 0 & 0 & 0 & 0 & 0 & 0 \\
\hline & & Reactions & 0 & 0 & 0 & 0 & 0 & 1 & 0 & 0 & 1 \\
\hline & \multicolumn{2}{|l|}{ Total } & 42 & 34 & 21 & 13 & 31 & 28 & 35 & 3 & 207 \\
\hline $\begin{array}{l}\text { Interests } \\
\text { groups and }\end{array}$ & Roles & $\begin{array}{l}\text { Knowledge } \\
\text { statement }\end{array}$ & 64 & 25 & 45 & 16 & 23 & 32 & 35 & 12 & 252 \\
\hline associations & & Explanation & 23 & 16 & 30 & 9 & 9 & 9 & 18 & 6 & 120 \\
\hline
\end{tabular}




\begin{tabular}{|c|c|c|c|c|c|c|c|c|c|c|c|}
\hline & & Evaluation & 54 & 13 & 17 & 10 & 14 & 26 & 34 & 6 & 158 \\
\hline & & Recommendations & 0 & 0 & 0 & 2 & 0 & 0 & 0 & 0 & 4 \\
\hline & & Reaction & 1 & 0 & 2 & 1 & 1 & 1 & 3 & 0 & 5 \\
\hline & \multicolumn{2}{|l|}{ Total } & 142 & 54 & 94 & 38 & 47 & 68 & 90 & 24 & 557 \\
\hline \multirow[t]{7}{*}{ Individuals } & \multirow[t]{6}{*}{ Roles } & Knowledge & 21 & 9 & 20 & 2 & 9 & 10 & 26 & 4 & 99 \\
\hline & & stat & & & & & & & & & \\
\hline & & Explanation & 11 & 1 & 3 & 1 & 2 & 6 & 8 & 0 & 27 \\
\hline & & Evaluation & 1 & 3 & 3 & 0 & 1 & 3 & 6 & 0 & 17 \\
\hline & & Recommendations & 0 & 0 & 0 & 0 & 0 & 0 & 0 & 0 & 0 \\
\hline & & Reaction & 6 & 2 & 9 & 0 & 0 & 1 & 4 & 0 & 22 \\
\hline & \multicolumn{2}{|l|}{ Total } & 39 & 15 & 35 & 3 & 12 & 20 & 44 & 4 & 172 \\
\hline \multirow[t]{6}{*}{ Total } & \multirow[t]{5}{*}{ Roles } & $\begin{array}{l}\text { Knowledge } \\
\text { statement }\end{array}$ & 622 & 235 & 434 & 134 & 176 & 349 & 318 & 52 & 1770 \\
\hline & & Explanation & 204 & 99 & 226 & 57 & 59 & 95 & 89 & 17 & 399 \\
\hline & & Evaluation & 128 & 23 & 56 & 28 & 46 & 73 & 77 & 21 & 275 \\
\hline & & Recommendations & 4 & 7 & 6 & 3 & 1 & 0 & 2 & 1 & 16 \\
\hline & & Reaction & 7 & 2 & 12 & 3 & 3 & 3 & 12 & 0 & 20 \\
\hline & \multicolumn{2}{|l|}{ Total } & 965 & 432 & 734 & 225 & 285 & 521 & 520 & 90 & 3772 \\
\hline
\end{tabular}

\footnotetext{
${ }^{\mathrm{i}}$ There is a distinction to recognise between the framing of issues and the framing of story themes. This research is concerned with recording the wider political framing of climate change as these are reproduced in news coverage. It does not treat the presence of story themes as framing (the distinction between these types has been the subject of recent debates in the framing literature). However, the research does take seriously the journalistic mediation of story themes and include them in its wider view of the determinants of news access opportunities.

ii The numbers of stories by newspaper are as follows: The Times 352 (25.5); The Telegraph 210 (15.2); The Independent 297 (21.2) and The Guardian 520 (37.7)
} 